\title{
Implementation Management of Modern Education in Madrasah Diniyah
}

\author{
Suharsono,
}

Nur Efendi ${ }^{2}$

1). Master of Islamic Education Management Universitas Muhammadiyah Sidoarjo, Indonesia Jl.Majapahit 666 B, Sidoarjo

2). Master of Islamic Education Management Universitas Muhammadiyah Sidoarjo, Indonesia Jl.Majapahit 666 B, Sidoarjo

sonosuhar22@gmail.com@umsida.ac.id

\begin{abstract}
Madrasah is an institution of Islamic education in Indonesia. Madrasah is one of the pillars of education, especially Islam. Madrasah existence has long been a part of education in Indonesia.

Principals are as one person in charge of educational institutions should be able to change the old paradigm into a new paradigm that is better in order to achieve the expected goals, as leader Principals are required to be able to move, influence, encourage, encourage, guide, advise, guide, ordering, commanding, forbidding, giving rewards, and give punishment (punishing, if necessary) and developing with the intention that man as a media management willing to work in order to achieve the purpose stated in the madrasah effectively and efficiently.

Behavior Management Principals in applying Modern Education in Madrasah Al-Ikhlas Diniyah Muhammadiyah Lamongan Sugihan solokuro appear once on the implementation of everyday tasks are always stressed and gave the example of the motto upright, Discipline, and Creative (IDK). Ikhlas is the spirit of the devotion and Discipline is the real form of devotion while Creative is the ability to generate ideas and action so that what ditampilakan not static and boring.

While the problems faced, ranging from problems of limited time, infrastructure, finance, and communication has not been established to the maximum, the usual problem faced by almost all educational institutions. But all this could be overcome by optimizing existing resources, as well as synergies with existing institutions, could be the best solution for the development and advancement of Madrasah Al-Ikhlas Diniyah this. The success of Islamic religious education in Madrasah Al-Ikhlas Diniyah Sugihan solokuro Muhammadiyah Lamongan, supported by the human resources component is very concerned about education. The success was evident from the seriousness of all the stakeholders, all of which was not separated from the help of Allah.
\end{abstract}

Keywords; Management, Education and Madrasah Diniyah

\section{INTRODUCTION}

Education is a positive step to achieve and reach a future more promising either the world or especially in the hereafter, and each person must take education regardless it formal, informal, or even non-formal though, all of which are designated in order to create a life that exist in the imagination and the diinginkanya.

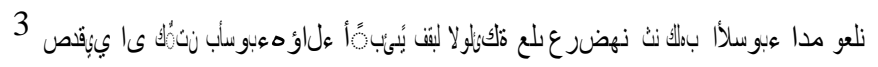

"And He taught the children of Adam the names (objects) entirely, then bring it to the angels and said," Tell me the names of these if you are truthful people are right. "(Surat . Al-Baqoroh: 31)

Each activity regardless of its form is need for regulation or management, in education shutter socalled educational management means managing or optimize the existing resources for the purpose of the creation of an effective education and efficient. This shows that management education is the process of planning, organizing, directing, and controlling educational resources to achieve the goals of Islamic education effectively and efficiently ${ }^{4}$, Madrasah is nuanced religious educational institutions in this respect the Islamic religion. Madrasah is one of the pillars in Islamic education. Which has been known since the 5th century. Madrasah first pre-Karsai by Nidzam

Al Mulk century to 10-11 AD, named Nizamiyyah in $1205 .^{5}$

Nidzam Al-Mulkitself is one of the Prime Minister during the reign of Bani Seljuk Caliphate. Besides Nidzamiyah, apparently before the 10th century has also been established a Madrasah in Nishapur city named after Al-Baihaqiyyah. ${ }^{6}$ 
In Indonesia alone, if you see the history of the religion is almost the same of the learning process that is teaching or Islamic studies conducted by teachers using halaqoh and sorogan more widely applied in various places of worship, or better known mosque, or in the Java language is violated and today is known as the small mosque just wide and long to distinguish the size smaller than the name of the mosque. At that time many madrasas are emerging in Indonesia, one of which is in Padang, West Sumatra, known as madrasas Adabiyahnya, and believed to be the first-established Madrasah in Indonesia, ${ }^{7 i n}$ recorded history that approximately year 1909 that Abdullah Ahmad as the founder of the madrasah, the forerunner to the development of madrasas at that time. And the next development then stood madrassas and other madrasas popping up in every region in the archipelago.

Before there was growth and renewal until the 10 th century, educational institutions is the dominant folk undeveloped madrasas and boarding. But the world is constantly changing, and At about the middle of the 20th century folk education institutions in the form of madrasas and boarding schools began to experience growth and development progress of time to adjust. And only in 1930 gradually the madrasas and boarding schools was renewed. The emergence of this reform movement is constituted by a desire for religious institutions in Indonesia has not experienced stagnation so behind in certain cases mainly in the fields of science and technology.

If the note in reality that madrasas in Indonesia have three forms that lead to learning provided;

1). Madrasah which is more directed at the modernity of applied learning focuses on common materials while religious instruction is given as support materials are added.

2). Madrassas prioritize religious instruction but does not rule out the general subject matter.

3). Madrasah which overall provides lessons devoted to religious materials and these are called madrassas diniyah.

Madrasah diniyah if grouped institutionally and in terms of its characteristics, there are three forms:

a). Diniyah madrasas as the embodiment of the ideals of the boarding school and is automatically located in boarding schools.

b). Madrasas diniyah embodied in the learning process is not much different from formal education, but devoted to religious materials and still maintain the old ways. And payload curriculum also result from his own institution or artificial of institutions themselves, and this is out of boarding school environment.

c). Diniyah madrasas were deliberately established with the aim to increase and mensyi'arkan sciences of religion to society and to the initiative and concern of the community itself, and the existing needs and existence of society and this environment is often called madrassas diniyah takmiliyah.

In fact in the public madrasah diniyah takmiliyah has become an alternative for parents who want their children to understand and able to practice the teaching of religion in accordance with the concept of Islamic education in schools, but they do not have the opportunity to send their children to boarding school or to enter into madrassas diniyah pure-run schools or madrassas diniyah which is the development of educational boarding school with general education facilities or madrasah diniyah second type.

Business madrasah diniyah takmiliyah this, has its own challenges where they become alternate parents, who for some reason have not had a chance to put their children in the boarding school, so they must have the tips and strategies in order to meet the expectations of parents and also be truly be the educators institutions (madrasas) that could provide religious education services as mandated.

Principals as one person in charge of educational institutions should be able to change the old paradigm into a new paradigm that is better in order to want to achieve the expected goals, because the leadership of the madrasah is to actualize the ability to influence and persuade and encourage other people to be able to do activities that could to realize the objectives of the madrassa / school are effective and efficient. ${ }^{9}$

The success and the success of education either school or madrassa dependent influencing factors, among others: the management (management), professionalism headmaster, teachers and employees of educational institutions, in short, all those involved directly or indirectly (stakeholders) in it, very determining a successful and whether or development level educational institutions. Diniyah Madrasah Al-Ikhlas Sugihan is one Diniyah madrassa in the village of the District Sugihan Solokuro Lamongan which continues to transform itself and to make improvements. So that its existence is different from other Diniyah Madrasah, even expected to be able to compete with other Diniyah Madrasah or Pesantren.

It is evident that the Madrasah Diniyah is still a focus for the community in providing education, especially religious education, so its presence is highly expected by parents who want to get their children have the basics of religion that is good and strong, both in terms of aqidah and worship. 


\subsection{Research approach}

\section{RESEARCH METHODS}

This study is a qualitative research, the researchers focused on the application and implementation of modern education management at Madrasah Al-Ikhlas Diniyah Wustho Muhammadiyah Sugihan year 2016/2017. While the approach used is the phenomenological approach. That explains the phenomenon that is mainly concerned with Modern Education Management implementation process, because there are a lot of educational institutions of Islam in its management cannot be handled professionally.

\section{a. Source of Data and Information}

Given the information gathered from this study is a model Management of Modern Education in Madrasah, the source of the data and information used are: principals, teachers, employees, and all involved in it and a network of supporting information in the form of data, documentation, publications and so forth.

b.Tehnik Data Collection

To obtain the required data the researchers used several methods:

\section{Observation}

In this observation, the authors observe the physical condition of the environment, observing teachers and employees, observing students in the environment, observe the infrastructure and facilities available at Madrasah Al-Ikhlas Diniyah SugihanSolokuro village of Lamongan. This method I use as an auxiliary method in conducting research, while understanding the observation by Suharsimi Arikunto he found: "Observation is a technique that is done by conducting thorough observation and recording systematically". ${ }^{10}$ So observation is a way to hold direct observation of the object that is going to study, to learn about the ins and outs and the things what happened then translated into written form.

\section{Interview (Interview)}

The interview is a conversation with a purpose. Conducted by the two parties, namely the interviewer (interviewer) who ask questions and interviewees (interviewee) which provides answers to questions. ${ }^{11}$ This method is used to obtain information about the guidelines that are used, steps towards management development, student development and student achievement Madrasah Al-Ikhlas Diniyah Sugihan Solokuro Lamongan village.

In this interview / interviews mostly done informally. For example, a visit to the sources, the dialogue in musholla universities, in places of rest where the study was developed.

Instruments used in this research is interview guide. The instrument is based on indicators that refers to the concept, the role of head of Madrasah and implementation of education management, teachers and employees.

\section{Documentation}

Method of documentation is searching techniques or collecting data through the physical form of goods related to such research writings in the form of a decision result of the meeting, transcripts, board structure, and so forth. ${ }^{12}$ Documentation is a supporting evidence of previously existing methods that observation, and interviews, so much stronger position and once more complete. To obtain the necessary documents and relevant researchers contacted the head of the Madrasah, teachers and employees Madrasah Al-Ikhlas Diniyah Wustho Sugihan Solokuro Muhammadiyah Lamongan village.

\section{Questionnaire (Questionnaire)}

Questionnaire is a way of obtaining data from respondents with questions or it could be a statement in accordance with the variables studied and accompanied existing answer choice. And the questionnaire method does not limit the number of respondents and questions or statements can be given directly. ${ }^{13}$ The results of the poll by the author made into the form of a narrative or didiskripsikan.

\section{c. Data Analysis Techniques}

If the data already collected the necessary next steps that researchers take to process the data through several stages of examination including the Triangulation of data, ie data validity checking techniques that take advantage of something else. Outside data for checking purposes or as a comparison against the data. ${ }^{14}$

The data processing method used by the author in this study are: 1) Reduction of Data / Data Reduction is clarifying the data that have been collected for more specifications on the issues to be addressed in the Study. 2). Presentation of Data / Display of data that is processing the existing data are grouped according to the subject of each issue so that further facilitate researchers in presenting and preparing for analysis, and in facilitating the presentation of the data is usually used in three ways; data checking, labeling / code, and tabulation. 3). Verification / Conclusion Drawing or could do with the interpretation of the data is to predict and describe various data sources have been investigated to reach a conclusion. 
Based on the three stages of analysis, then analyzed theme is useful to describe and display the meaning of the whole so that the focal point of research in the capture. To be more convincing in the study findings it is necessary to be supported by the references or bibliography. in analyzing the data expected interaction of EMIC approach is an approach that makes the essence of the right to a language or a culture at any given time; This approach is an attempt to reveal and describe patterns of a language or a particular culture of how the elements of language or culture is relative to one another in performing the function in accordance with the pattern. Pedekatan ethical approach is a complex consisting of a set of goals and procedures.

Instead of conduct-emic approach to library materials that are theoretically related to the theme that has been arranged, in order to strengthen and expand the evidence used as the basis of the conclusions. Tests conducted on the interpretation of earlier chapters in describing logical or causal to obtain evidence strengthening the conclusions from a variety of sources, so the chapters presented here is an integral and systematic and intact.

\section{RESULTS AND DISCUSSION}

Implementation of means of implementation, implementation. ${ }^{15}$ Thus the implementation is the process of applying ideas, concepts, policies, or innovation in a practical action so as to give effect to the impact both in the form of changes in knowledge, skills and values, and attitudes. While Madrasah Diniyah itself is one of religious educational institutions on the outside lane of the school is expected to continuously provide Islamic education to students who are not being met at schools has given through the classical system and implement education.

The existence of rural communities is far different than the urban community, both from the aspect industry, information, mental and moral perspective as well as science and technology is (Science and Technology). Reality is happening these needs are often slow to arrive to rural communities, as well as the majority of them are in the lower economic level. This is a consideration for madrasah institutions in order to realize the needs and expectations of all parties to the educational quality of his form. However, be unique if the only people willing to become lecturers and education in Islamic educational institutions are still new without adequate incentives and even not at all. This is a verification term often came out of our mouths"lillahi Ta'ala", which is working for Allah alone, and in fact this is actually happening in Islamic educational institutions. Rarely this happens in the world of education, especially at the present moment.

Based on the above it can be concluded that the author is a Management Implementation of Modern Education in Madrasah Diniyah can be defined as a process of applying ideas, concepts, and policy on Management Education in an Diniyah Madrasah management activities.

Establishment of the Madrasah Al-Ikhlas Diniyah Wustho Sugihan Muhammadiyah is an answer to the concerns of society, especially the residents of the village of Lamongan Solokuro Sugihan will lack religious education acquired by their children, and also read the reality on the ground that the study of the Qur'an is needed amid being surrounded complexity of life and bustle competition diverse. ${ }^{16}$

Along with the passage of time and the discovery of a method of reading the Qur'an are simple and very popular at the time, the method of Iqra ', initiated by As'ad cleric Humam of Jogjakarta, it was established TKA and land fill in the village Sugihan, with all sorts of management systems follow the standards specified by LPTQ or LKP2 Lamongan, the body which manages and shade TK / TPA nationally. ${ }^{17}$ Even though the various shortcomings stand TK / TPA Al-Ikhlas Sugihan Solokuro Lamongan in 1990, which is managed independently by Sugihan Muhammadiyah youth and adolescents. Alhamdulillah development of TK / TPA so rapidly, and also enthusiastic communities make TK / TPA could thrive, and has managed santri early childhood and kindergarten age were able to read the Qur'an fluently.

Modern education management model characterized by their plans / intentions, organizing, and monitoring. As well as the concept of sincerity, honesty, trust, fairness, responsibility, dynamic, and flexible in carrying out duties at the school.

Success or failure depends on management practices several components, namely; human resources (eg, principals, teachers, employees) material / instrumental (eg, school buildings, props), the environment (including, parents, communities, local governments or agencies related), and education (eg, whole teaching and learning activities) as well as the curriculum or learning.

The concept and practice of management in Madrasah Al-Ikhlas Diniyah Sugihan Solokuro Lamongan formed through the harmonious cooperation between component-omponen madrasah. Whereas in the implementation of management, a manager / headmaster always based on concepts that have been didirencanakan. For example, at the beginning of the school year a manager / headmaster draw up a work program that is used as a guideline in carrying out activities in the institution. While in the organization collects human resources followed by the delegation of tasks to employees / co-workers like homeroom, teachers and employees. Apart from that a manager in this case the headmaster always provide motivation and direction to all teachers, employees and even students to always carrying out duties in accordance with their respective fields that inspired the motto IDK (Ikhlas, Discipline and Creative) that will appear and produce 
new innovations that are the hallmark and the traits possessed by the institution itself. What has been done by Principals Diniyah Wustho al-Ikhlas is a mirror-led character as Motivator.

On every 25th or beginning of the fourth week of each month in an effort to establish silaturrahim and also a form of concern, in order to know the condition of cleric / cleric who has a problem, so it can be resolved. With this evaluation will also be able to note the extent to which the implementation of the programs implemented madrassa.

For the development of professionalism in carrying out duties headmaster selalau conduct regular training, both on the methods of learning and administration, as well as sending teachers or employees if there is a training which was held at the district level and provincial level. Thus the management applied in this Madin is the leader or the head of the Madrasah as Supervisor of learning.

Learning activities at the school to run smoothly because the headmaster is able to appoint his assistants in accordance with the duties and membership of each (the righ man on the righ place). Maid's headmaster performing the task that has been determined by the headmaster as well as the specifications of the subject teachers who teach according to their expertise.

Besides, on demand as well as to conduct an evaluation of all activities at the school. Also the principle that emphasizes sincerity and ruhul jihad in the implementation of their daily duties, and emphasized togetherness and transparency in carrying out the task.

Aside from being a school principal has the task manager as administrator and educator. As a manager Principals Diniyah Al-Ikhlas Sugihan Solokuro Lamongan is responsible for all activities in Madrasah Diniyah, which is always held in cooperation with teachers, staff and community. Principals assign tasks to Ustadz / cleric to carry out the activities that have been programmed by the institution in accordance with the madrasah program.

Meanwhile, as the chief administrator of Madrasah Diniyah Al-Ikhlas Sugihan Solokuro Lamongan master the material in depth for each subject and for each grade level, and to develop teaching programs with a teacher for one year in the future, even though the program compiled mostly still in a very simple form, coordinate activities with all stakeholders, oversee the implementation of the evaluation study preparation activities preparatory coordinate teaching and evaluation. Besides the role of head of Madrasah Diniyah AlIkhlas Sugihan Solokuro Lamongan is composing the division and job descriptions, set staffing, organize household matters madrasah, governs the relationship between the leadership, teachers, students, parents and the community as well as to control the conduct of all activities in madrassas.

As an educator head Madrasah also have the same duties like other educators that provide guidance and counseling to students, teachers and employees, and also it was given to teaching in the classroom and this is the embodiment of professionalism.

In carrying out everyday tasks Principals Diniyah Al-Ikhlas Sugihan Solokuro Lamongan assisted by cleric / cleric collectively mngelola curriculum areas, areas of infrastructure, student field and the field of public relations division of duties adapted to the respective field of work. Although there is no certainty division but Principals collectively assign tasks based on the opportunity and ability to solve problems at the time. Madin head is function- oriented organization optimalifungsi of sub-system that works effectively in achieving the objectives specified. ${ }^{18}$

Besides Madrasah Diniyah Al-Ikhlas Sugihan Solokuro Lamongan curriculum living modified curriculum of the Ministry of Religious Affairs (MORA) with curriculum developed by Madrasah themselves with the concept of simplicity, given the limitations of which are owned by the Madrasah Diniyah Al-Ikhlas, so the curriculum is the hallmark of Madrasah Al-Ikhlas Diniyah Sugihan.

The success of Madrasah Education Diniyah Al-Ikhlas Sugihan Solokuro Lamongan not be separated from the cooperation between the components comprising a component of human resources, material / instruments as well as components of human lingkungan.Sumber in Madrasah Al-Ikhlas Diniyah Sugihan Solokuro Lamongan, partly great teachers are adequate and in accordance with the rules in the Act of RI. No. 14 of 2005 on teachers and lecturers, the teachers must be educated to degree level or D.4.

While the material component or instrumental in Madrasah Diniyah Al-Ikhlas Sugihan Solokuro Lamongan not yet have its own building, still use building complex college Muhammadiyah of MIM 07 or MTsM 06 Sugihan as learning room while the teacher's room or office is already a provision Leader Leaves Muhammadiyah Sugihan, while the props and other supporting materials to support teaching and learning in Madrasah Al-Ikhlas Diniyah Sugihan overall have not fully fulfilled and that too is not a significant obstacle to the learning process in Madin Wustho Sugihan Al-Ikhlas.

As if not perfect if the management of educational institutions there are constraints and also weaknesses that are owned or in the language of the Qur'an is Likewise in the management of Madrasah Diniyah Al-Ikhlas Muhammadiyah village Sugihan is of course there are also obstacles and barriers, despite these obstacles do not dampen the spirit of struggle and sacrifice of the builder / Ustadz and Ustadzahnya manage madrasah diniyah it, but if look for a solution hopefully be problem solving which injected separately and added strength and complement deficiency, Obstacles encountered, and influential in determining Diniyah Madrasah development are: 


\section{The limited time}

The learning activities Madrasah Al-Ikhlas Diniyah implemented after maghrib prayer congregation until the adhan for Isha '. In short time makes this learning activity seemed to be less effective, and it does not become a barrier implementation of learning activities even though it is felt not maximized.

\section{Facilities and Means inadequate}

Facilities owned by Diniyah Madrasah Al-Ikhlas is not yet perfect. Various deficiencies still occur here and there. Among others are;

a. Classrooms are still a loan owned MTsM 06 Sugihan so that time can be 06 Insist that if MTsM no activity.

b. Yet have its own teachers' room

c. Headroom and TU still together

\section{Funding}

Sources of funds obtained from the trustee of students and the local government, but the number is far from enough to hold the development and well equip facilities and infrastructure. Merely to give honor to the chaplain/ cleric although it is still considered far from enough. Meanwhile, besides the operational funds be used to cover operational deficiencies still used to meet religious teacher salaries are lacking.

\section{Cooperation among the relevant parties}

Cooperation with related parties which could help the development of Madrasah Diniyah still needs to be improved, for example cooperation with formal institutions, which could be an asset additions students. Besides communication with guardians of students are still less intensive, is evidenced by the still less awareness of carers to pay attention to the activity of their children in the following study in Madrasah Diniyah Wustho Al- Ikhlas Muhammadiyah Sugihan, often children do not attend but without confirmation of parents

\section{CONCLUSION}

The conclusion of the research on Modern Education Management implentasi at Madrasah Al-Ikhlas Diniyah

Wustho Muhammamadiyah sugihan Solokuro Lamongan is as follows:

1. In memenej / managing madrasah, the Principals are always based on the concept of planning to all activities of the madrasas to draw up a work program that aims to regulate all activities in Madrasah. To carry out the various activities that have been programmed, Madrasah Al-Ikhlas Diniyah Wustho Sugihan Solokuro Muhammadiyah Lamongan forming and organizing Ustadz / Ustadzah to assist in their respective fields. Supervision to any personnel each to make a report as a responsibility to the mandate of its mission. Behavior Management Principals in applying Modern Education in Madrasah Al-Ikhlas Diniyah Wustho appear once on the implementation of everyday tasks are always stressed and gave the example of the motto upright, Discipline, and Creative (IDK).

2. While the problems faced, ranging from problems of limited time, infrastructure, finance, and communication has not been fully established, is a common problem faced by almost all educational institutions. But all this could be overcome by optimizing existing resources, as well as synergies with existing institutions, could be the best solution for the development and advancement of Madrasah Al-Ikhlahs Diniyah this.

Educational success supported by the human resources components namely; (Principals, teachers, staff and trustees who care to education). The success was evident from the seriousness of all the stakeholders, all of which was not separated from the help of Allah .. This is evidenced by the strong interest of the public to remain entrust the religious education of their children at Madrasah Al-Ikhlahs Diniyah this. Public confidence in Madrasah Al-Ikhlas Diniyah Wustho increasingly apparent by looking at the development of this Madrasah, which was originally only a study group to read the Qur'an into Madrasah Diniyah which already has more than

113

students.

\section{Thank-you note}

Thank the author goes to:

1. Dr. Hidayatullah, M.Si, as the Rector of the University of Muhammadiyah Sidoarjo.

2. Dr. Istikomah, M.Ag, as Dean of the Faculty of Islamic Studies, University of Muhammadiyah Sidoarjo.

3. Dr. Nyong ETIS, M.Fil.I as the Head Master of Management Islamic Education University of Muhammadiyah Sidoarjo.

4. The entire community Madrasah Diniyah Wustho Al-Ikhlas Muhammadiyah Sugihan Solokuro Lamongan. 


\section{BIBLIOGRAPHY}

1. Arifin, Islamic Education. Jakarta: Earth Literacy, 2011.

2. M. Islamic Education An Overview of Theoretical and Practical Based on Interdisciplinary Approach. Jakarta: Earth Literacy 2011.

3. Arikunto, Suharsimi. Fundamentals of Educational Evaluation. Jakarta: Earth Literacy, 2013.

4. Procedure Research and Practice approach. Jakarta: Earth Literacy, 1988.

5. Mujamil Qomar. Dimensions of Islamic Education Management. Erland, 2015

6. Fatah, Nana. The cornerstone of education management. Bandung: Teen Rosda paper, 2001.

7. Handoko, Hani T. Management. Jogyakarta: BPFE, 1995.

8. Moleong, Lexy J. Metodologgi Qualitative Research. Bandung: Youth Rosdakarya 2002.

9. MPR.RI. Constitution of the Republic of Indonesia. 1945 and its amendments. Solo: Adzana Son.

10. Mulyasa, E. Kompetemsi based curriculum, concepts, characteristics, and Implementation. Bandung: Youth Rosdakarya 2004.

11. Mulyasa, E. Being Principal Professional, Bandung: Youth Rosdakarya 2009.

12. Nata, Abudin. Paradigm of Islamic Education, Capita Selecta Islamic Education, Jakarta: TP 2001.

13. Nata, Abudin. History of Islamic Education in Classical and Medieval Period, RajaGrafindo Persada, 2013.

14. Suryabrata, Sumadi. Research Methodology, RajaGrafindoPersada, 2014.

15. Rachman Saleh. Madrasah Nations Children and Education, RajaGrafindo persada 2004

16. Soepardi in E. Mulyasa, School Based Management, Concepts and Implementation Strategy. Bandung: PT. Youth Rosdakarya 2004

17. Umar Yusuf, Madrasah Education Management Quality, Bandung: Refika Aditama, 2016.

18. UU.RI. No. 20, 2003, On the National Education System. Jakarta: Caldera Pustaka Nusantara 2003. [

19. Quran and Terjemahnya. Al Quran Al Karim King Fahd Al Madinah Al Munawwaroh.

20. Sugiyono, o Methods of qualitative and quantitative research R \& D Alfabeta, 2014.

21. Amtu Onisimus, Education Management in the Era of Regional Autonomy, Bandung: Alfabeta, 2013.

22.Jahari Jaja \& Syarbini Amirulloh, Madrasah Management Theory, Strategy, and Implementation. Bandung: Alfabeta, 2013.

23. Karel Steenbrink A, Pesantren Islam Madrasah School Education in Modern period, LP3ES 1994.

24. Lecturer team UPI Education Administration, Management Education, Bandung: Alfabeta 20. 